\title{
ANALISIS FAKTOR-FAKTOR YANG MEMPENGARUHI PRODUKSI DAN PERMINTAAN KARET ALAM DI INDONESIA
}

\author{
ANALYSIS OF FACTORS THAT INFLUENCE PRODUCTION \\ AND DEMAND OF NATURAL RUBBER \\ IN INDONESIA
}

\author{
${ }^{1}$ Haryanto, ${ }^{2}$ Sunariyo, ${ }^{3}$ Abdul Mukti \\ ${ }^{1}$ Alumnus Program Studi Agribisnis Fakultas Pertanian Universitas Palangka Raya \\ ${ }^{2,3}$ Staf Pengajar Program Studi Agribisnis Fakultas Pertanian Universitas Palangka Raya \\ email: sunariyodiris@agb.upr.ac.id
}

\begin{abstract}
ABSTRAK
Penelitian dilaksanakan untuk mengetahui faktor-faktor yang mempengaruhi produksi dan permintaan karet alam di Indonesia. Penelitian ini menggunakan data runtun waktu (time series) periode tahun 1986-2016. Analisis menggunakan model ekonometrika dalam bentuk persamaan simultan dan diduga dengan metode 2SLS (Two Stage Least Square) dibantu menggunakan aplikasi SAS 9.1 (Statistical Analysis System). Dalam pendugaannya dibagi dalam dua blok (blok produksi dan blok permintaan) dimana dalam setiap blok terdiri dari dua persamaan struktural. Berdasarkan hasil dugaan parameter tersebut dapat disimpulkan: pada blok produksi, respon produksi karet alam di Indonesia (QKR) dipengaruhi oleh luas area karet menghasilkan (AKR), harga karet alam domestik (HKR), harga ekspor karet alam (HXKR) dan permintaan karet alam Indonesia (DKR) dengan masing-masing pengaruh sebesar $(0,2926 ; 0,0480 ; 0,0222$ dan 0,8841). Respon harga karet alam domestik (HKR) yang mempengaruhi produksi karet alam di Indonesia dipengaruhi oleh harga karet alam dunia (HKRD), ekspor karet alam (XKR) dan nilai tukar Rupiah terhadap Dolar Amerika Serikat (ER) dengan masing-masing pengaruh sebesar $(0,2112 ; 2,4562$ dan 571,6580). Pada blok permintaan, respon permintaan karet alam Indonesia (DKR) dipengaruhi oleh harga karet alam domestik (HKR) dan jumlah kendaraan bermotor (JKB) dengan masing-masing pengaruh sebesar $(-0,0176$ dan 0,0082$)$. Respon ekspor karet alam (XKR) yang sebelumnya mempengaruhi harga karet alam domestik (HKR) dipengaruhi oleh produksi karet alam di Indonesia (QKR), harga ekspor karet alam (HXKR) dan nilai tukar Rupiah terhadap Dolar Amerika Serikat (ER) dengan masing-masing pengaruh sebesar $(0,2664 ; 0,0238$ dan 26,8898).
\end{abstract}

Kata Kunci: Permintaan karet, persamaan simultan, produksi karet, two stage least square (2 SLS)

\section{ABSTRACT}

The research is aimed to know factor affect rubber and demand in Indonesia. This research is used time series period from 1989 until 2016. The analyze used econometric model in the form of simultaneous aquations with Two Stage Least Square Method and helped Statistical Analyze System consisting. Its divided into two block (Production and Demand block) where every block consisting two structural aquations. Result showed that production block, natural rubber production response $(Q K R)$ is affected by area of rubber produces (AKR), price of domestic natural rubber (HKR), price of export natural rubber (HXKR) and Indonesia 
natural rubber demand (DKR) with each affect of 0,2926, 0,0480, 0,0222, and 0,8841. Price response of domestic natural rubber $(H K R)$ is affected by price of world natural rubber (HKRD), export of natural rubber (XKR) and the rupiah against the dollar of USA (ER) with each affect of 0,2112; 2.4562 and 571,6580). It's demand block, response of Indonesia natural rubber demand (DKR) is affected by price of domestic natural rubber (HKR) and number of vehicles $(\mathrm{JKB})$ with each affect of $-0,0176$ and 0,0082. Before response of export of nutural rubber (XKR) affects price of domestic natural rubber (HKR). Its affected by production of Indonesia natural rubber (QKR), price of export of natural rubber (HXKR) and the rupiah against the dollar of USA (ER) with each affect of 0,2664;0,0238 and 26,8898.

Keywords: Rubber demand, rubber production, simultaneous aquations, two stage least square (2 SLS)

\section{PENDAHULUAN}

\section{Latar Belakang dan Permasalahan}

Karet alam pertama kali ditemukan sebagai tanaman liar di suatu daerah pedalaman Amerika oleh Michele de Cuneo pada tahun 1493. Penemuan teknologi dibidang perkaretan menjadikan industri karet dunia semakin berkembang. Selain itu pertumbuhan ekonomi dunia, memberi dampak pertumbuhan permintaan karet alam yang cukup tinggi. Menurut International Rubber Study Group (IRSG), diperkirakan akan terjadi kekurangan pasokan karet alam pada periode dua dekade ke depan, hal ini menjadi kekhawatiran pihak konsumen. Sehingga pada tahun 2004, IRSG membentuk Task Force Rubber Eco Project (REP) untuk melakukan studi tentang permintaan dan penawaran karet sampai dengan tahun
2035. Hasil studi REP meyatakan bahwa permintaan karet alam dan sintetik dunia pada tahun 2035 adalah sebesar 31,3 juta ton untuk industri ban dan non ban, dan 15 juta ton diantaranya adalah karet alam (Direktorat Jenderal Perkebunan, 2016).

Keseimbangan konsumsi dan produksi karet alam dunia aktual dan proyeksinya disajikan pada Tabel 1 . Keadaan tersebut memperlihatkan bahwa rasio produksi dan konsumsi karet alam memiliki nilai kurang dari satu, khususnya pada tahun 2018 sampai dengan 2020 yang dapat diartikan bahwa telah dan akan terjadi defisit penawaran karet alam dunia. Jika kondisi defisit penawaran karet alam tersebut terjadi akan menjadi indikasi bahwa harga harapan karet alam dunia akan mengalami peningkatan, mempunyai tren positif, atau tetap berada pada tingkat harga yang tinggi.

Tabel 1. Produksi dan Konsumsi Karet Alam Dunia Aktual dan Proyeksi

\begin{tabular}{cccc}
\hline Tahun & $\begin{array}{c}\text { Konsumsi Karet Alam } \\
\text { Dunia (Juta Ton) }\end{array}$ & $\begin{array}{c}\text { Produksi Karet Alam } \\
\text { Dunia (Juta Ton) }\end{array}$ & $\begin{array}{c}\text { Rasio Produksi dan Konsumsi } \\
\text { Karet Alam Dunia }\end{array}$ \\
\hline 2011 & 11,0 & 11,2 & 1,02 \\
2012 & 11,6 & 12,1 & 1,05 \\
2013 & 11,4 & 12,2 & 1,07 \\
2014 & 11,8 & 11,8 & 1,00 \\
$\left.2018^{*}\right)$ & 15,3 & 14,0 & 0,09 \\
$\left.2020^{*}\right)$ & 16,5 & 15,2 & 0,92 \\
\hline
\end{tabular}

Keterangan: $*$ ) $=$ Angka proyeksi

Sumber: International Rubber Study Group dalam Hendratno, 2015.

Indonesia merupakan salah satu negara yang memiliki kontribusi dalam memenuhi permintaan karet alam dunia melalui besaran ekspor dari produksi yang 
dihasilkan. Produksi karet alam Indonesia pada tahun 2015 sebesar 3.145.398 ton, dengan besaran produksi tersebut Indonesia merupakan negara penghasil karet alam terbesar ke dua di dunia setelah Thailand (Pusat Data dan Sistem Informasi Pertanian, 2016).

Karet alam hingga kini merupakan salah satu komoditi perkebunan yang mempunyai peranan penting bagi Indonesia. Peranan penting tersebut diantaranya sebagai sumber perolehan devisa negara, penyediaan lapangan kerja dan merupakan sumber pendapatan bagi petani karet maupun bagi pelaku ekonomi lainnya yang terlibat dalam budidaya, pengolahan ataupun perdagangan karet. Kini perkembangan perkebunan karet di Indonesia tidak lagi bergairah, hal tersebut bisa dilihat dari produksi karet yang dihasilkan justru mengalami penurunan. Penurunan tersebut bisa dilihat pada Tabel 2 berikut.

Tabel 2. Tingkat Penurunan Produksi Karet Alam di Indonesia

\begin{tabular}{lccccc}
\hline \multirow{2}{*}{ Tahun } & \multicolumn{5}{c}{ Produksi (Ton) } \\
\cline { 2 - 6 } & PR & PBN & PBS & Indonesia & Pertumbuhan $(\%)$ \\
\hline 2010 & 2.179 .061 & 266.326 & 289.467 & 2.734 .854 & \\
2011 & 2.359 .811 & 302.370 & 328.003 & 2.990 .184 & 9,34 \\
2012 & 2.377 .228 & 304.602 & 330.424 & 3.012 .254 & 0,74 \\
2013 & 2.655 .942 & 255.616 & 325.875 & 3.237 .433 & 7,48 \\
2014 & 2.583 .439 & 227.783 & 341.964 & 3.153 .186 & $-2,60$ \\
2015 & 2.568 .633 & 225.999 & 350.766 & 3.145 .398 & $-0,25$ \\
$\left.2016^{*}\right)$ & 2.575 .237 & 226.270 & 356.272 & 3.157 .780 & 0,39 \\
$\left.2017^{* *}\right)$ & 2.638 .071 & 227.288 & 364.503 & 3.229 .861 & 2,28 \\
\hline Rata-rata & 2.492 .178 & 254.532 & 335.909 & 3.082 .619 & 2,48 \\
\hline
\end{tabular}

Keterangan : *) = Angka Sementara

$$
\begin{aligned}
& * *)=\text { Angka Estimasi } \\
& \text { PBN = Perkebunan Besar Negara } \\
& \text { PR = Perkebunan Rakyat } \\
& \text { PBS = Perkebunan Besar Swasta }
\end{aligned}
$$

Sumber: Direktorat Jenderal Perkebunan Komoditas Karet, Tahun 2016.

Berdasarkan Tabel 2 di atas, dapat dilihat bahwa terjadi penurunan produksi karet alam di Indonesia pada tahun 2014, 2015 dan 2016 dimana angka produksi yang dihasilkan lebih rendah dari angka pada tahun 2013. Keadaan tersebut justru tidak searah dengan semakin prospektif pasar karet di lingkup internasional yang diperkirakan akan terjadi peningkatan harga dikarenakan produksi yang dihasilkan berdasarkan proyeksi tidak mampu memenuhi kebutuhannya.

Dari sisi permintaan akan kebutuhan karet alam domestik, hingga kini produksi karet alam di Indonesia hanya mampu diserap untuk memenuhi permintaan dalam negeri rata-rata tahun
2010 hingga 2016 hanya sebesar 20,52\% sisanya digunakan untuk memenuhi kebutuhan ekspor (Direktorat Jendral Perkebunan, 2016).

Dengan keadaan tersebut guna menyikapi peluang dalam bidang perkaretan di Indonesia, maka penelitian mengenai "Faktor-Faktor yang Mempengaruhi Produksi dan Permintaan Karet Alam di Indonesia" perlu dilakukan, sehingga faktor-faktor yang mempengaruhi produksi dan permintaan karet alam di Indonesia dapat diketahui.

\section{Tujuan Penelitian}

Berdasarkan latar belakang dan permasalah yang telah dikemukakan maka 
penelitian ini bertujuan untuk mengetahui faktor-faktor yang mempengaruhi produksi dan permintaan karet alam di Indonesia.

\section{TINJAUAN PUSTAKA}

\section{Tanaman Karet}

\section{Karet (Hevea brasiliensis)}

merupakan spesies tanaman yang termasuk dalam famili Euphorbiace atau tanaman getah-getahan. Dinamakan golongan famili ini karena memiliki jaringan tanaman yang banyak mengandung getah (lateks) dan getah tersebut mengalir keluar apabila jaringan tanamannya terlukai. Hibitus tanaman ini merupakan pohon dengan tinggi tanaman yang dapat mencapai 15-20 m. Modal utama dalam pengusahaan tanaman ini adalah batang setinggi 2,5 sampai $3 \mathrm{~m}$ dimana terdapat pembuluh lateks. Oleh karena itu fokus tanaman karet adalah bagaimana mengelola batang tanaman ini seefisien mungkin. Agar bisa diperoleh produksi dan mutu karet yang tinggi, maka fokus budidaya harus diperhatikan dengan baik (Anonim, 2010).

\section{Teori Produksi dan Fungsi Produksi}

Produksi sering diartikan sebagai penciptaan guna, yaitu kemampuan barang dan jasa untuk memenuhi kebutuhan manusia. Teori produksi terdiri dari beberapa analisa mengenai bagaimana seharusnya seorang pengusaha dalam tingkat teknologi tertentu, mampu mengkombinasikan berbagai macam faktor produksi untuk menghasilkan sejumlah produk tertentu dengan seefisien mungkin. Jadi, penekanan proses produksi dalam teori produksi adalah suatu aktivitas ekonomi yang mengkombinasikan berbagai macam masukan (input) untuk menghasilkan suatu keluaran (output) (Soekartawi et al., 1995).

Fungsi produksi menurut Malone dalam Karosekali (2015) adalah suatu fungsi atau persamaan yang menunjukkan hubungan fisik atau teknis antara faktorfaktor yang digunakan dengan jumlah produk yang dihasilkan per satuan waktu, tanpa memperhatikan harga, baik harga faktor-faktor produksi maupun harga produk. Fungsi produksi menurut Sukirno (2005), menunjukkan sifat hubungan antara faktor produksi dan tingkat produksi yang dihasilkan. Selanjutnya dalam (Soekartawi et al., 1995), fungsi produksi didefinisikan sebagai hubungan teknis antara input dengan output, dimana hubungan ini menunjukkan output sebagai fungsi dari input. Bentuk persamaan matematis dari fungsi produksi pada dasarnya merupakan abstraksi dari proses produksi yang di sederhanakan.

Secara matematis sederhana, fungsi produksi dapat ditulis sebagai berikut:

$$
\begin{aligned}
& \text { Output }= f(\text { input }) \\
& \mathbf{Q}=f\left(\mathbf{X}_{\mathbf{1}}, \mathbf{X}_{\mathbf{2}}, \mathbf{X}_{\mathbf{3}}, \ldots, \mathbf{X}_{\mathbf{i}}\right)
\end{aligned}
$$

Keterangan:

$\mathrm{Q}=$ output

$\mathrm{X}_{\mathrm{i}}=$ input yang digunakan dalam proses produksi; $\mathrm{i}=1,2,3, \ldots, \mathrm{n}$

Dari persamaan di atas fungsi produksi dalam beberapa pembahasan ekonomi banyak diminati dan dianggap penting karena:

1. Fungsi produksi dapat menjelaskan hubungan antara faktor produksi dengan produksi itu sendiri secara langsung dan hubungan tersebut dapat lebih mudah dimengerti.

2. Fungsi produksi mampu mengetahui hubungan antara variabel yang dijelaskan (Q), dengan variabel yang menjelaskan (X) serta sekaligus mampu mengetahui hubungan antar variabel penjelasnya (antara $\mathrm{X}$ dengan $\mathrm{X}$ yang lain).

\section{Konsep Permintaan}

Menurut Sicat \& Arndt (1991), permintaan didefinisikan sebagai jumlah unit barang dan jasa yang ingin dibeli oleh konsumen pada periode waktu dan keadaan-keadaan tertentu. Besarnya permintaan pada suatu barang biasanya 
dihubungkan dengan tingkat harga. Hubungan antara harga dan kuantitias suatu komoditas dapat dijelaskan dengan kurva matematik, yaitu dengan menggambarkan hubungan antara harga dan jumlah komoditas yang diminta. Sifat hubungan antara harga dan jumlah yang diminta dinamakan hukum permintaan. Ilustrasi dari konsep permintaan dalam kurva dapat dilihat pada Gambar 1.

Gambar 1. Kurva Permintaan Suatu Produk

Menurut Fathurrazi \& Joesron (2012) secara matematis permintaan pada suatu barang dapat dirumuskan melalui faktorfaktor yang mempengaruhi permintaan akan barang tersebut. Hal tersebut dirumuskan sebagai berikut:

Keterangan:

$$
D_{x}=f\left(P_{x}, Y, P_{y}, T, u\right)
$$

$\mathrm{D}_{\mathrm{x}}=$ Jumlah barang yang diminta

$\mathrm{P}_{\mathrm{X}}=$ Harga barang itu sendiri

$\mathrm{Y}=$ Pendapatan konsumen

$\mathrm{P}_{\mathrm{y}}=$ Harga barang lain

$\mathrm{T}=$ Selera

$\mathrm{u}=$ Faktor-faktor lain

Apabila terjadi perubahan faktor yang mempengaruhi permintaan selain harga, maka akan terjadi perubahan permintaan. Perubahan permintaan tersebut apabila digambarkan dalam sebuah kurva, maka kurva tersebut mengalami pergeseran permintaan ke atas atau ke bawah.

\section{Model Persamaan Simultan}

Model persamaan simultan merupakan persamaan yang memiliki ciri variabel terikat pada suatu persamaan menjadi variabel penjelas pada sistem persamaan yang lainnya (Gujarati, 1997). Menurut Supranto (1984), persamaan simultan dapat didefinisikan sebagai suatu model yang mempunyai hubungan sebab akibat antara variabel dependen dan variabel independennya, sehingga suatu variabel dapat dinyatakan sebagai variabel dependen maupun independen dalam persamaan yang lain. Namun pada model persamaan simultan tidak lagi menggunakan penyebutan variabel bebas dan variabel terikat tetapi menggunakan penyebutan variabel eksogen dan endogen. Perbedaan penyebutan ini dikarenakan pada persamaan regresi variabel terikat hanya bisa dipengaruhi oleh variabel bebas dan variabel terikat tidak bisa mempengaruhi variabel bebasnya.

Langkah pengerjaan sistem persamaan simultan diawali dengan melakukan identifikasi model. Identifikasi model digunakan untuk menentukan apakah persamaan bersifat under identified (tidak teridentifikasi), exactly identified (tepat teridentifikasi), atau overidentified (teridentifikasi berlebihan). Penentuan identifikasi ini sangat penting karena menentukan cara penyelesaian dari persamaaan simultan. Apabila persamaan teridentifikasi exactly identified maka metode yang tepat adalah Indirect Least Square (ILS) sedangkan apabila teridentifikasi over identified maka persamaan diselesaikan dengan (Two Stage Least Square (2SLS).

\section{Tinjauan Terhadap Penelitian Terdahulu}

Kajian terdahulu mengenai faktorfaktor yang mempengaruhi produksi dan permintaan karet alam di Indonesia dengan menggunakan persamaan simultan masih belum banyak dilakukan. Berikut beberapa tinjauan terdahulu yang dikaji dan relevan dengan penelitian ini. Napitupulu (2004), mengemukakan bahwa faktor-faktor yang mempengaruhi produksi karet di Indonesia diantaranya: harga ekspor karet alam, harga karet alam dunia, nilai tukar rupiah terhadap dolar Amerika Serikat, produktivitas perkebunan karet rakyat dan perkebunan besar serta luas area perkebunan karet Indonesia. Pada persamaan yang dibangun, keempat variabel eksogen pada persamaan penduga produksi karet alam Indonesia memiliki nilai koefisien regresi positif. Model yang dibangun dapat menjelaskan faktor yang 
mempengaruhi produksi karet di Indonesia sebesar $95 \%$.

Sunariyo (2015), hasil penelitian tersebut mengemukakan bahwa permintaan karet alam di Indonesia diduga dipengaruhi oleh harga karet alam domestik dan jumlah kendaraan bermotor di Indonesia. Pada persamaan yang dibangun harga karet domestik memiliki hubungan negatif terhadap permintaan karet alam di Indonesia sedangkan jumlah kendaraan bermotor di Indonesia memiliki hubungan positif. Penyusunan model tersebut mampu menjelaskan perilaku permintaan karet alam di Indonesia sebesar $72 \%$.

\section{METODE PENELITIAN}

Penelitian ini menggunakan data runtun waktu (time series) periode tahun 1986-2016. Data yang dikumpulkan diperoleh dari publikasi Direktorat Jenderal Perkebunan Nasional, Badan Pusat Statistik, Word Bank, Bank Indonesia dan hasil publikasi penelitian terdahulu. Analisis menggunakan model ekonometrika dalam bentuk persamaan simultan dan diduga dengan metode Two Stage Least Square (2SLS) dibantu menggunakan aplikasi Statistical Analysis System (SAS 9.1).

Dalam penelitian faktor-faktor yang mempengaruhi produksi dan permintaan karet alam di Indonesia dibagi dalam dua blok yaitu blok produksi dan blok permintaan. Masing-masing blok terdiri dari dua persamaan struktural. Variabelvariabel yang dimasukan dalam persamaan struktural adalah variabel yang dihipotesiskan dalam penelitian yang diperoleh setelah melakukan respesifikasi sampai variabel tersebut memenuhi kriteria statistik, ekonometrika danekonomi yang sesuai.

\section{Blok Produksi}

\section{Respon Produksi Karet Alam}

$$
\begin{aligned}
& \mathrm{QKR}_{\mathrm{t}}=\mathrm{a}_{0}+\mathrm{a}_{1} \mathrm{AKR}_{\mathrm{t}}+\mathrm{a}_{2} \mathrm{HKR}_{\mathrm{t}}+\mathrm{a}_{3} \mathrm{HXKR}_{\mathrm{t}}+\mathrm{a}_{4} \mathrm{DKR}_{\mathrm{t}}+\mathrm{U}_{\mathrm{t}} \\
& \text { Keterangan: } \\
& \mathrm{QKR}_{\mathrm{t}}= \text { Produksi Karet Alam (ton/tahun) } \\
& \mathrm{AKR}_{\mathrm{t}}= \begin{array}{l}
\text { Luas Area Karet menghasilkan } \\
\text { (ha) }
\end{array} \\
& \mathrm{HKR}_{\mathrm{t}}= \begin{array}{l}
\text { Harga Karet Alam Domestik } \\
\text { (Rp/ton) }
\end{array} \\
& \mathrm{HXKR}_{\mathrm{t}}=\begin{array}{l}
\text { Harga Ekspor Karet Alam } \\
\text { (Rp/ton) }
\end{array} \\
& \mathrm{DKR}_{\mathrm{t}}=\begin{array}{l}
\text { Permintaan Karet } \\
\text { Indonesia (ton/ha) }
\end{array}
\end{aligned}
$$

Hipotesis parameter dugaan: $a_{1}, a_{2}, a_{3}$ dan $\mathrm{a}_{4}>0$

\section{Respon Harga Karet Indonesia}

$$
\begin{gathered}
\mathrm{HKR}_{\mathrm{t}}=\mathrm{b}_{0}+\mathrm{b}_{1} \mathrm{HKRD}_{\mathrm{t}}+\mathrm{b}_{2} \mathrm{XKR}_{\mathrm{t}}+\mathrm{b}_{3} \mathrm{ER}_{\mathrm{t}} \\
+\mathrm{U}_{\mathrm{t}}
\end{gathered}
$$

Keterangan:

$$
\begin{aligned}
\mathrm{HKR}_{\mathrm{t}}= & \begin{array}{l}
\text { Harga Karet Alam Domestik } \\
(\mathrm{Rp} / \text { ton })
\end{array} \\
\mathrm{HKRD}_{\mathrm{t}}= & \begin{array}{c}
\text { Harga Karet Alam Dunia } \\
(\mathrm{Rp} / \text { ton})
\end{array} \\
\mathrm{XKR}_{\mathrm{t}}= & \text { Ekspor Karet Alam (ton/tahun) } \\
\mathrm{ER}_{\mathrm{t}}= & \text { Nilai Tukar Rupiah Terhadap } \\
& \text { Dolar Amerika Serikat }(\mathrm{Rp} / \$)
\end{aligned}
$$

Hipotesis parameter dugaan: $b_{1}, b_{2}$ dan $b_{3}>$ 0

\section{Blok Permintaan}

\section{Respon Permintaan Karet Alam Indonesia}

$$
\mathrm{DKR}_{\mathrm{t}}=\mathrm{c}_{0}+\mathrm{c}_{1} \mathrm{JKB}_{\mathrm{t}}+\mathrm{c}_{2} \mathrm{HKR}_{\mathrm{t}}+\mathrm{U}_{\mathrm{t}}
$$

Keterangan:

$$
\begin{aligned}
\text { DKR }_{\mathrm{t}}= & \begin{array}{l}
\text { Permintaan Karet Indonesia } \\
\text { (ton/tahun) }
\end{array} \\
\mathrm{HKR}_{\mathrm{t}}= & \text { Harga Karet Domestik (Rp/ton) } \\
\mathrm{JKB}_{\mathrm{t}}= & \begin{array}{l}
\text { Jumlah Kendaraan Bermotor } \\
\text { (Unit) }
\end{array}
\end{aligned}
$$

Hipotesis parameter dugaan: $\mathrm{c}_{1}>0$ dan $\mathrm{c}_{2}<$ 


\section{Respon Ekspor Karet Indonesia}

$$
\begin{gathered}
\mathrm{XKR}_{\mathrm{t}}=\mathrm{d}_{0}+\mathrm{d}_{1} \mathrm{QKR}_{\mathrm{t}}+\mathrm{d}_{2} \mathrm{HXKR}_{\mathrm{t}}+\mathrm{d}_{3} \mathrm{ER}_{\mathrm{t}} \\
+\mathrm{U}_{\mathrm{t}}
\end{gathered}
$$

Keterangan :

$$
\begin{aligned}
\mathrm{XKR}_{\mathrm{t}}= & \begin{array}{l}
\text { Ekspor Karet Indonesia } \\
\text { (ton/tahun) }
\end{array} \\
\mathrm{QKR}_{\mathrm{t}}= & \begin{array}{l}
\text { Produksi Karet Alam Domestik } \\
\text { (ton/tahun) }
\end{array} \\
\mathrm{HXKR}_{\mathrm{t}}= & \begin{array}{l}
\text { Harga Ekspor Karet Indonesia } \\
\text { (Rp/ton) }
\end{array} \\
\mathrm{ER}_{\mathrm{t}}= & \begin{array}{l}
\text { Nilai Tukar Rupiah Terhadap } \\
\text { Dolar }(\mathrm{Rp} / \mathrm{US} \$)
\end{array}
\end{aligned}
$$

Hipotesis parameter dugaan: $d_{1}, d_{2}$, dan $d_{3}$ $>0$

\section{Identifikasi dan Pendugaan Model}

Pada penelitian ini terdapat sebanyak 4 peubah endogen $(\mathrm{G})$ dan 5 peubah eksogen $(\mathrm{M})$, dengan jumlah peubah (endogen dan eksogen) dalam persamaan yang diidentifikasi sebanyak 9 peubah.

$$
(\mathrm{K}-\mathrm{M}) \geq(\mathrm{G}-1)
$$

Jika $(\mathrm{K}-\mathrm{M})<(\mathrm{G}-1)$, maka persamaan under identified

Jika $(\mathrm{K}-\mathrm{M})=(\mathrm{G}-1)$, maka persamaan excatly identified

Jika $(\mathrm{K}-\mathrm{M})>(\mathrm{G}-1)$, maka persamaan over identified

Berdasarkan banyak peubah endogen dan eksogen serta jumlah peubah eksogen dan endogen, dalam persamaan yang diidentifikasi maka penelitian ini terpenuhi kriteria $(\mathrm{K}-\mathrm{M})>(\mathrm{G}-1)$, artinya persamaan dalam penelitian ini termasuk over identified. Dengan demikian metode Two Stage Least Square (2SLS) dapat digunakan untuk menduga parameter struktural dari model yang telah di spesifikasikan.

\section{HASIL DAN PEMBAHASAN}

Berdasarkan evaluasi secara teoritis dan kompromistis antara kriteria statistik, ekonometrika dan ekonomi terhadap model yang telah disusun, maka keempat model tersebut telah memenuhi persyaratan dan layak digunakan untuk menduga faktor yang mempengaruhi produksi dan permintaan karet alam di Indonesia.

Dari keempat persamaan yang dibangun memiliki nilai $\mathrm{Pr}>\mathrm{F}$ sebesar 0,0001 (sangat signifikan), dari hasil uji $F_{\text {hitung }}$ tersebut menunjukkan bahwa seluruh variabel penjelas (variabel eksogen) yang menyusun model secara bersama-sama berpengaruh nyata terhadap variabel endogennya. Nilai koefisien determinasi $\mathrm{R}^{2}$ pada ke empat persamaan memiliki nilai antara 0,77-0,96. Nilai $\mathrm{R}^{2}$ yang sebagian besar berada pada nilai yang tinggi menunjukkan bahwa variabel-variabel penjelas (variabel eksogen) yang dimasukkan dalam model telah mampu menggambarkan perilaku dari variabel endogennnya.

Selanjutnya hasil uji serial korelasi atau autokorelasi dengan menggunakan uji Durbin-Watson pada $\alpha=5 \%$ menunjukkan bahwa sebanyak empat persamaan yaitu produksi karet alam di Indonesia (QKR), harga karet alam domestik (HKR), permintaan karet Indonesia (DKR) dan ekspor karet alam (XKR) mempunyai nilai $\mathrm{d}<4-\mathrm{d}_{\mathrm{U}}$ maka diputuskan tidak menolak $\mathrm{H}_{0}$ (menerima $\mathrm{H}_{0}$ ) yang menunjukkan bahwa tidak terjadi serial korelasi negatif.

\section{Blok Produksi}

\section{Respon Produksi Karet Alam di Indonesia (QKR)}

Hasil analisis persamaan produksi karet alam Indonesia (QKR) menunjukkan nilai $F_{\text {hitung }}$ sebesar 145,33 dan signifikan pada taraf 0,0001. Koefisien determinasi $\mathrm{R}^{2}$ sebesar 0,96 dan nilai Durbin-Watson sebesar 1,3859. Berdasarkan hasil uji $F_{\text {hitung }}$ dapat diinterprestasikan bahwa secara simultan keempat variabel yang dihipotesiskan berpengaruh nyata terhadap produksi karet alam Indonesia (QKR). Berdasarkan nilai koefisien determinasi $\mathrm{R}^{2}$ menunjukkan bahwa perubahan keempat variabel yang dimasukkan dalam model mampu menjelaskan sebesar $96 \%$ dari perilaku variabel endogennya, sedangkan sisanya $4 \%$ dipengaruhi oleh variabel lain yang tidak dimasukkan dalam model. 
Selanjutnya dari nilai Durbin-Watson berdasarkan kriteria pengujiannya menunjukkan bahwa pada persamaan tidak terjadi serial korelasi negatif atau autokorelasi pada taraf kesalahan 5\%.

Hasil pengujian secara parsial luas area karet menghasilkan (AKR), harga karet alam domestik (HKR), harga ekspor karet alam (HXKR) dan permintaan karet alam Indonesia (DKR) berpengaruh nyata (signifikan pada taraf 0,1137, 0,0133, 0,0044 dan 0,0028 ) terhadap produksi karet alam di Indonesia (QKR). Dengan hasil tersebut menunjukkan bahwa seluruh variabel penjelas (variabel eksogen) yang dimasukkan dalam model secara persial berpengaruh nyata (signifikan). Koefisien arah dari keempat variabel telah sesuai dengan hipotesis yang disusun dan memenuhi kriteria ekonomi, statistik dan ekonometrik yang ditetapkan yaitu positif pada keempat variabel yang dimasukkan. Secara ringkas hasil pendugaan persamaan respon produksi karet alam di Indonesia (QKR) dapat dilihat pada Tabel 3 berikut.

Tabel 3. Hasil Pendugaan Parameter Persamaan Respon Produksi Karet Alam di Indonesia (QKR)

\begin{tabular}{lrr}
\hline \multicolumn{1}{c}{ Independent Variable } & Parameter Estimate & Prob $>|\mathrm{t}|$ \\
\hline Intercept & 142352,2 & 0,8045 \\
Luas areal karet menghasilkan (AKR) & $0,2926^{*}$ & 0,1137 \\
Harga karet alam domestik (HKR) & $0,0478^{* * *}$ & 0,0133 \\
Harga ekspor karet alam (HXKR) & $0,0222^{* * *}$ & 0,0044 \\
Permintaan karet alam Indonesia (DKR) & $0,8841^{* * *}$ & 0,0028 \\
\hline F-Value & 145,33 & \\
Pr $>$ F & 0,0001 & \\
$\mathrm{R}^{2}$ & 0,96 & \\
Durbin-Watson & 1,3859 & \\
\hline
\end{tabular}

Keterangan: *) nyata pada taraf kepercayaan $88,63 \%$, ***) nyata pada taraf kepercayaan $98,67 \%, 99,56 \%$ dan $99,72 \%$

Sumber: Hasil olah data.

\section{Respon Harga Karet Alam Domestik (HKR)}

Hasil analisis persamaan harga karet alam domestik (HKR) menunjukkan nilai $\mathrm{F}_{\text {hitung }}$ sebesar 119,19 dan signifikan pada taraf 0,0001. Koefisien determinasi $\mathrm{R}^{2}$ sebesar 0,93 dan nilai Durbin-Watson sebesar 1,2702. Berdasarkan hasil uji $\mathrm{F}_{\text {hitung }}$ dapat diinterprestasikan bahwa secara simultan keempat variabel yang dihipotesiskan yaitu harga karet alam dunia (HKRD), nilai tukar Rupiah terhadap Dolar Amerika Serikat (ER) dan ekspor karet alam (XKR) berpengaruh nyata terhadap harga karet alam domestik (HKR). Berdasarkan nilai koefisien determinasi $\mathrm{R}^{2}$ menunjukkan bahwa perubahan keempat variabel yang dimasukkan dalam model mampu menjelaskan sebesar $93 \%$ dari perilaku variabel endogennya, sedangkan sisanya $7 \%$ dipengaruhi oleh variabel lain yang tidak dimasukkan dalam model. Selanjutnya dari nilai Durbin-Watson berdasarkan kriteria pengujiannya menunjukkan bahwa pada persamaan tidak terjadi serial korelasi positif atau autokorelasi pada taraf 5\%.

Hasil pengujian secara parsial harga karet alam dunia (HKRD) dan nilai tukar Rupiah terhadap Dolar Amerika Serikat (ER) berpengaruh nyata (signifikan pada taraf 0,1661 dan 0,0077) terhadap harga karet alam domestik (HKR). Sedangkan ekspor karet alam (XKR) berpengaruh pada taraf 0,5680 terhadap harga karet alam domestik (HKR).Koefisien arah dari 
variabel telah sesuai dengan hipotesis yang disusun dan memenuhi kriteria ekonomi, statistik dan ekonometrik yang ditetapkan yaitu positif pada ketiga variabel yang dimasukkan. Secara ringkas hasil pendugaan persamaan respon harga karet alam domestik (HKR) dapat dilihat pada Tabel 4.

Tabel 4. Hasil Pendugaan Parameter Persamaan Respon Harga Karet Alam Domestik (HKR)

\begin{tabular}{lrr}
\hline \multicolumn{1}{c}{ Independent Variable } & Parameter Estimate & Prob $>|\mathrm{t}|$ \\
\hline Intercept & -2780143 & 0,54100 \\
Harga karet alam dunia (HKRD) & 0,2112 & 0,1661 \\
Nilai tukar Rupiah terhadap Dolar AS (ER) & $571,6580 * * *$ & 0,0077 \\
Ekspor karet alam (XKR) & 2,4562 & 0,5680 \\
\hline F-Value & 119,19 & \\
Pr $>$ F & 0,0001 & \\
$\mathrm{R}^{2}$ & 0,93 & \\
Durbin-Watson & 1,2702 & \\
\hline
\end{tabular}

Keterangan : ***) nyata pada taraf kepercayaan 99,23\%

Sumber: Hasil olah data.

Blok Permintaan

\section{Respon Permintaan Karet Alam Indonesia (DKR)}

Permintaan karet alam Indonesia (DKR) merupakan persamaan perilaku atau persamaan struktural, dimana permintaan karet alam Indonesia (DKR) merupakan selisih dari total produksi karet Indonesia dikurangi dengan total ekspor karet alam Indonesia ditambah dengan total impor karet alam Indonesia.

Hasil analisis persamaan permintaan karet alam Indonesia (DKR) menunjukkan nilai $F_{\text {hitung }}$ sebesar 46,28 dan signifikan pada taraf 0,0001 . Koefisien determinasi $\mathrm{R}^{2}$ sebesar 0,77 dan nilai Durbin-Watson sebesar $\quad 1,4286$. Berdasarkan hasil uji $F_{\text {hitung dapat }}$ diinterprestasikan bahwa secara simultan kedua variabel yang dihipotesiskan berpengaruh nyata terhadap permintaan karet alam Indonesia (DKR). Berdasarkan nilai koefisien determinasi $\mathrm{R}^{2}$ menunjukkan bahwa perubahan kedua variabel yang dimasukkan dalam model mampu menjelaskan sebesar $77 \%$ dari perilaku variabel endogennya, sedangkan sisanya $23 \%$ dipengaruhi oleh variabel lain yang tidak dimasukkan dalam model. Selanjutnya dari nilai Durbin-Watson berdasarkan kriteria pengujiannya menunjukkan bahwa pada persamaan tidak terjadi serial korelasi negatif atau autokorelasi pada taraf 5\%.

Hasil pengujian secara parsial jumlah kendaraan bermotor (JKB) berpengaruh nyata (signifikan pada taraf $0,0001)$ terhadap permintaan karet alam di Indonesia (DKR), dan pada variabel harga karet alam domestik (HKR) berpengaruh nyata pada taraf 0,1343 terhadap permintaan karet alam Indonesia (DKR). Koefisien arah variabel telah sesuai dengan hipotesis yang disusun dan memenuhi kriteria ekonomi, statistik dan ekonometrik yang ditetapkan yaitu positif pada variabel JKB dan negatif pada variabel HKR. Secara ringkas hasil pendugaan persamaan respon permintaan karet alam Indonesia (DKR) dapat dilihat pada Tabel 5 berikut. 
Tabel 5. Hasil Pendugaan Parameter Persamaan Respon Permintaan Karet Alam Indonesia (DKR)

\begin{tabular}{lrr}
\hline \multicolumn{1}{c}{ Independent Variable } & Parameter Estimate & Prob > $|\mathrm{t}|$ \\
\hline Intercept & 98564,49 & 0,0267 \\
Jumlah kendaraan bermotor (JKB) & $0,0082^{* * *}$ & 0,0001 \\
Harga karet alam domestik (HKR) & $-0,0176^{*}$ & 0,1343 \\
\hline F-Value & 46,28 & \\
Pr $>$ F & 0,0001 & \\
$\mathrm{R}^{2}$ & 0,77 & \\
Durbin-Watson & 1,4286 & \\
\hline
\end{tabular}

Keterangan: *) nyata pada taraf kepercayaan $86,57 \%$

Sumber: Hasil olah data.

$$
* * *) \text { nyata pada taraf kepercayaan } 99,99 \%
$$

\section{Respon Ekspor Karet Alam Indonesia (XKR)}

Hasil analisis persamaan ekspor karet alam Indonesia (XKR) menunjukkan nilai $F_{\text {hitung }}$ sebesar 124,48 dan signifikan pada taraf 0,0001. Koefisien determinasi $\mathrm{R}^{2}$ sebesar 0,93 dan nilai Durbin-Watson sebesar 1,2934. Berdasarkan hasil uji $\mathrm{F}_{\text {hitung }}$ dapat diinterprestasikan bahwa secara simultan ketiga variabel yang dihipotesiskan yaitu produksi karet alam di Indonesia (QKR), harga ekspor karet alam (HXKR) dan nilai tukar Rupiah terhadap Dolar Amerika Serikat (ER) berpengaruh nyata terhadap ekspor karet alam Indonesia (XKR). Berdasarkan nilai koefisien determinasi $\mathrm{R}^{2}$ menunjukkan bahwa perubahan ketiga variabel yang dimasukkan dalam model mampu menjelaskan sebesar $93 \%$ dari perilaku variabel endogennya, sedangkan sisanya $7 \%$ dipengaruhi oleh variabel lain yang tidak dimasukkan dalam model. Selanjutnya nilai Durbin-Watson berdasarkan kriteria pengujiannya menunjukkan bahwa pada persamaan tidak terjadi serial korelasi negatif atau autokorelasi pada taraf 5\%.

Hasil pengujian secara parsial produksi karet alam di Indonesia (QKR), harga ekspor karet alam (HXKR) dan nilai tukar Rupiah terhadap Dolar Amerika Serikat (ER) berpengaruh nyata (signifikan pada taraf 0,0703, 0,0031 dan 0,0430) terhadap ekspor karet alam Indonesia (XKR). Dengan hasil tersebut menunjukkan bahwa seluruh variabel penjelas (variabel eksogen) yang dimasukkan dalam model secara persial berpengaruh nyata (signifikan). Koefisien arah dari ketiga variabel telah sesuai dengan hipotesis yang disusun dan memenuhi kriteria ekonomi, statistik dan ekonometrik yang ditetapkan yaitu positif pada ketiga variabel yang dimasukkan. Secara ringkas hasil pendugaan persamaan respon ekspor karet alam Indonesia (XKR) dapat dilihat pada Tabel 6 berikut.

Tabel 6. Hasil Pendugaan Parameter Persamaan Respon Ekspor Karet Alam Indonesia (XKR)

\begin{tabular}{lrr}
\multicolumn{1}{c}{ Independent Variable } & Parameter Estimate & Prob $>|\mathrm{t}|$ \\
\hline Intercept & 747094,9 & 0,0001 \\
Produksi karet alam Indonesia (QKR) & $0,2664 * *$ & 0,0703 \\
Harga ekspor karet alam (HXKR) & $0,0238^{* * *}$ & 0,0031 \\
Nilai tukar Rupiah terhadap dolar AS (ER) & $26,8897 * * *$ & 0,0430 \\
\hline
\end{tabular}




\begin{tabular}{lr}
\hline $\mathrm{F}-$ Value & 124,48 \\
$\mathrm{Pr}>\mathrm{F}$ & 0,0001 \\
$\mathrm{R}^{2}$ & 0,93 \\
Durbin-Watson & 1,2934
\end{tabular}

Keterangan: **) nyata pada taraf kepercayaan 99,69\% dan 95,70\% ***) nyata pada taraf kepercayaan $92,97 \%$

Sumber: Hasil olah data.

\section{KESIMPULAN DAN SARAN}

\section{Kesimpulan}

Berdasarkan hasil dan pembahasan penelitian yang telah dilakukan maka dapat ditarik kesimpulan sebagai berikut:

1. Produksi karet alam di Indonesia (QKR) dipengaruhi oleh luas area karet menghasilkan (AKR), harga karet alam domestik (HKR), harga ekspor karet alam (HXKR) dan permintaan karet alam Indonesia (DKR). Harga karet alam domestik (HKR) yang mempengaruhi produksi karet alam di Indonesia dipengaruhi oleh harga karet alam dunia (HKRD), ekspor karet alam (XKR) dan nilai tukar Rupiah terhadap Dolar Amerika Serikat (ER).

2. Permintaan karet alam Indonesia (DKR) dipengaruhi oleh harga karet alam domestik (HKR) dan jumlah kendaraan bermotor (JKB). Sementara ekspor karet alam (XKR) yang mempengaruhi harga karet alam domestik (HKR) dipengaruhi oleh produksi karet alam di Indonesia (QKR), harga ekspor karet alam (HXKR) dan nilai tukar Rupiah terhadap Dolar Amerika Serikat (ER).

\section{Saran}

Bagi pemerintah dan organisasi terkait untuk meningkatkan produksi karet alam di Indonesia, peran pemerintah guna meningkatkan luas area karet menghasilkan dengan peremajaan pada tanaman karet tua dan bantuan terhadap faktor produksi dalam usaha perkebunan karet perlu dilakukan. Skema pemerintah dalam mengatur harga tetap stabil perlu diperhatikan, dengan pembatasan ekspor, peningkatan dan penurunan pajak ekspor guna menjaga kestabilan harga karet Indonesia.

Untuk meningkatkan permintaan karet alam di Indonesia, perlu adanya kontrol dari pemerintah maupun organisasi terkait untuk menjaga kestabilan harga karet alam di Indonesia agar permintaan dan produksi karet alam Indonesia tetap stabil dan dapat berkembang.

\section{DAFTAR PUSTAKA}

Anonim. (2010). Pedoman Bertanam Karet. Bandung: Nuansa Aulia. Bandung

Direktorat Jenderal Perkebunan. (2016). Rencana Strategis Direktorat Jenderal Perkebunan Tahun 20152019. Jakarta.

Fathurrazi, M. \& Joesron, T. S. 2012. Teori Ekonomi Mikro. Yogyakarta: Graha Ilmu.

Gujarati, N. D. (1997). Ekonometrika Dasar. Terjemahan. Jakarta: Erlangga.

Hendratno, S. (2015). Analisis Perkembangan Pasar Karet Remah SIR. Jurnal Warta Perkaretan Vol. 34: 161-176.

Karoskali, A. S. (2015). Analisis FaktorFaktor yang Mempengaruhi Permintaan dan Penawaran Kedelai di Sumatera Utara. Tesis. Universitas Sumatra Utara. Medan.

Napitupulu, MT. D. (2004). Model Perdagangan Karet Alam Indonesia. Disertasi. Program Pascasarjana Universitas Brawijaya. Malang.

Pusat Data dan Sistem Informasi Pertanian. (2016). Outlook Karet Komoditas 
Pertanian Subsektor Perkebunan.

Jakarta.

Sicat, G.P. \& Arndt, H. W. (1991). Ilmu

Ekonomi Untuk Konteks Indonesia. Jakarta: LP3ES.

Soekartawi., Soeharjo, A., Dillon, J. L. \& Hardaker, J. B. 1995. Ilmu Usahatani dan Penelitian Untuk Pengembangan Petani Kecil. Jakarta: Universitas Indonesia.

Sukirno, S. (2005). Mikro Ekonomi Teori Pengantar. Jakarta: Rajawali Pers.

Sunariyo. (2015). Dampak Liberalisasi Perdagangan Terhadap Kinerja Ekonomi Komoditas Kelapa Sawit dan Karet di Indonesia. Disertasi. Universitas Brawijaya. Malang.

Supranto, J. (1984). Ekonometrik Buku Dua. Jakarta: Universitas Indonesia. 